\title{
Feeding ecology of Leporinus taeniofasciatus (Characiformes: Anostomidae) before and after installation of a hydroelectric plant in the upper rio Tocantins, Brazil
}

\author{
Miriam P. Albrecht and Erica Pellegrini-Caramaschi
}

The feeding ecology of Leporinus taeniofasciatus in the upper rio Tocantins was characterized before (river phase) and after (reservoir phase) its impoundment by the Serra da Mesa Hydroelectric Dam. The importance of each food item was given by the Alimentary Index (IAi), which combines the frequency of occurrence and volumetric methods. A significant difference in the diet of L. taeniofasciatus between seasons in the river phase, detected by a multivariate analysis of variance, was not kept when the reservoir was formed. Its feeding activity, verified through the percentage of stomachs with different degrees of fullness, was not affected by the impoundment. Leporinus taeniofasciatus was able to incorporate terrestrial food items to its diet when they became abundantly available at the beginning of reservoir formation. Despite this plasticity, secondary factors such as predation and competition might have affected its adaptation in the new, more homogeneous environment. Its diet was not significantly different in the lotic sites between the distinct phases, suggesting that the remaining upstream lotic environments still provide favorable conditions for this species, reinforcing the need to preserve those habitats, as L. taeniofasciatus, which is apparently endemic to the Tocantins basin, may be threatened.

A ecologia alimentar de Leporinus taeniofasciatus no alto rio Tocantins foi caracterizada antes (fase rio) e após (fase reservatório) seu represamento pela Usina Hidrelétrica Serra da Mesa. A importância de cada item alimentar foi dada pelo Índice Alimentar (IAi), que combina os métodos de freqüência de ocorrência e volumétrico. Uma diferença sazonal significativa na dieta de $L$. taeniofasciatus durante a fase rio, que não foi mantida durante a formação do reservatório, foi detectada através de uma análise de variância multivariada. A atividade alimentar, verificada pela porcentagem de estômagos com diferentes graus de repleção, não foi afetada pelo represamento. L. taeniofasciatus foi capaz de incorporar itens alimentares terrestres a sua dieta quando estes se tornaram abundantes no começo da formação do reservatório. Apesar desta plasticidade, fatores secundários tais como predação ou competição podem ter afetado sua adaptação no ambiente novo e mais homogêneo. Sua dieta não foi significativamente diferente nas localidades lóticas entre as fases distintas, sugerindo que os ambientes lóticos remanescentes à montante ainda provêem condições favoráveis para esta espécie. Este fato reforça a necessidade de preservar estes ambientes, uma vez que $L$. taeniofasciatus, aparentemente endêmica à bacia do Tocantins, pode estar ameaçada.

Key words: diet, fish, Neotropical, reservoir.

\section{Introduction}

The construction of large dams remains a prevailing practice in Brazil to supply the increasing demand of energy, despite the numerous negative effects of such projects (e.g. Mérona et al., 1987; Agostinho et al., 1992; Agostinho et al., 1999). The rio Tocantins had its upper stretch impounded by the Serra da Mesa Hydroelectric Dam in October 1996.

Current data estimate a total of approximately 200 fish species for this track (Figueiredo et al., in press). The family Anostomidae, endemic to South America, consists of about
10 genera and 100 species (Géry, 1977), and is represented by 14 species in the studied area. Leporinus taeniofasciatus was recently described by Britski (1997), and no information about its biology had yet been made available. According to current data, this species is restricted to the Tocantins basin. It was recorded as one of the ten most important species in frequency and biomass in the affected region of the reservoir prior to the impoundment. However, from October 1997 on, it has been encountered only in the remaining upstream lotic sites (Pellegrini-Caramaschi et al., in press).

A major impact of reservoirs is to reduce the natural

Laboratório de Ecologia de Peixes, Departamento de Ecologia, Universidade Federal do Rio de Janeiro, Ilha do Fundão, P. O. Box 68020, 21941-541 Rio de Janeiro, RJ, Brazil. e-mail: biu@acd.ufrj.br (EPC); mpalbrecht@ig.com.br (MPA) 
periodicity of rivers, and a common response at the community level is the gradual reduction of species diversity. Some fish respond very quickly to impoundment whereas others respond gradually over years or decades, according to their trophic nature (Agostinho et al., 1999).

As diet and plasticity seem to be primary factors influencing distribution and differential survival of species after the damming of rivers (Hahn et al., 1997), the study of their feeding and interaction with the environment supplies crucial information on the fish community in reservoirs. In comparison to temperate ecosystems, long-term alterations are less predictable for tropical reservoirs. Hahn et al. (1997) pointed out some associated problems, such as the lack of knowledge about the autoecology of many species, their generalized diet plasticity, the endemic features of each system, and the lack of consistent, long-term studies on the natural environment prior to the impact caused by the impoundment. According to Agostinho et al. (1999), the effects of damming can be monitored through studies on the before-after intervention type, and the management of reservoirs should aim not only to increase fisheries production but also to maintain species diversity.

Our data, combined with that obtained for other species, will allow the proposal of management strategies for the area impacted by the dam. In this paper we characterize the feeding ecology of L. taeniofasciatus in the upper rio Tocantins and relate it to environmental changes, both natural (hydrological regime) and anthropogenic (impoundment). The reduced occurrence of L. taeniofasciatus in the area under the influence of the impoundment leads us to hypothesize that its feeding ecology was affected by dam construction.

\section{Material and Methods}

The study area is located in the upper rio Tocantins, Brazil $\left(48^{\circ} 06^{\prime} / 49^{\circ} 06^{\prime} \mathrm{W}\right.$ and $\left.13^{\circ} 34^{\prime} / 14^{\circ} 44^{\prime} \mathrm{S}\right)$ (Fig. 1), which was impounded in 1996 by the Serra da Mesa Hydroelectric plant. The reservoir filled until reaching its current size of $1724 \mathrm{~km}^{2}$ in April 1998, when the dam started operating to generate energy. Before the impoundment, the affected portion of the river was a succession of waterfalls, riffles and pools within constrained reaches, surrounded by cerrado vegetation, a type of wet seasonal savanna occurring mostly in central Brazil (Felfili \& Silva Jr., 1993). This region has a well-defined hydrological regime: high waters, from November to April, and low waters, from May to October.

Fish were captured bimonthly with a standardized set of gill nets left for $24 \mathrm{hrs}$ and monitored every $8 \mathrm{hrs}$ in 14 selected sites on the upper rio Tocantins, Brazil (Fig. 1), from February 1996 to April 1998. This period comprises the river phase (February 1996 to October 1996), corresponding to the natural river condition prior to damming, and reservoir phase (December 1996 to April 1998), corresponding to the filling stage, when sampling sites already presented lentic characteristics. Some remaining lotic sites were also sampled after the impoundment. In order to detect changes related to seasons, reservoir formation, or a combination of both, these phases were subdivided in river/flood, river/drought, reservoir/ flood and reservoir/drought, each of them encompassing a six-month period. The captured specimens were measured, weighed and their digestive tract removed and fixed in 5\% formaldehyde.

Voucher specimens were deposited at the Museu de Zoologia da Universidade de São Paulo: MZUSP 51073 (holotype) and 51074, 51212-51219 (paratypes), and also at the Museu Nacional do Rio de Janeiro: MNRJ 15210.

The gut contents of 183 specimens of L. taeniofasciatus with standard length between $8.1 \mathrm{~cm}$ and $15.8 \mathrm{~cm}$ (mean $=11.2$ $\mathrm{cm}$ ) were analyzed. Food items were separated to categories and their volume was measured in a $1 \mathrm{~mm}$ high square-shaped transparent dish with a scale in millimeters underneath so that the area corresponded to the volume. Food items were identified to the lowest suitable taxonomic category and listed. Nevertheless, for graphical representation and statistical purposes the data was grouped in 22 categories, as shown in the results.

The frequency of occurrence (Hynes, 1950; Hyslop, 1980) and volumetric (quantitative) measurements were combined in the Alimentary Index (IAi) proposed by Kawakami \& Vazzoler (1980) to characterize the diet.

In order to assess feeding activity, the degree of fullness of each stomach was recorded as follows: $1(<25 \%) ; 2$ (25$50 \%) ; 3(50-75 \%)$ and $4(75-100 \%)$. The percentage of half-full $(1 ; 2)$ and totally full stomachs $(3 ; 4)$ was verified for river and reservoir environments.

A multivariate analysis of variance was performed in the MULTIV software (Pillar, 1999) to test significant differences in the diet of L. taeniofasciatus related to environmental changes, such as season and reservoir formation. In this method each individual (stomach) is treated as a sampling unit and each prey as a variable, whose value is given by its volume relative to the total volume of stomach content ( $\mathrm{VO} \%$ ). A randomization test was performed with 1000 iterations in order to test comparisons between groups of sampling units. These units were defined by two factors, namely season/ phase (river/ flood, river/ drought, reservoir/ flood and reservoir/ drought), and flow/ phase (river/ lotic, reservoir/ lotic and reservoir/ lentic). As the aforementioned analysis is akin to a conventional analysis of variance, differing only in the way probabilities are obtained, results are interpreted similarly. For details see Pillar \& Orlóci (1996).

\section{Results}

All 22 food categories were found in the stomach contents of $L$. taeniofasciatus in the river phase, and 18 were present in the reservoir phase, when seasonal differences are not accounted for. The frequency of occurrence (FO\%), percentual volume (VO\%) and IAi values for each item are shown in Table 1. The graphical representation of IAivalues of the main food items in the river and reservoir environments is shown in Fig. 2. Vegetal material (plant debris and seeds + 


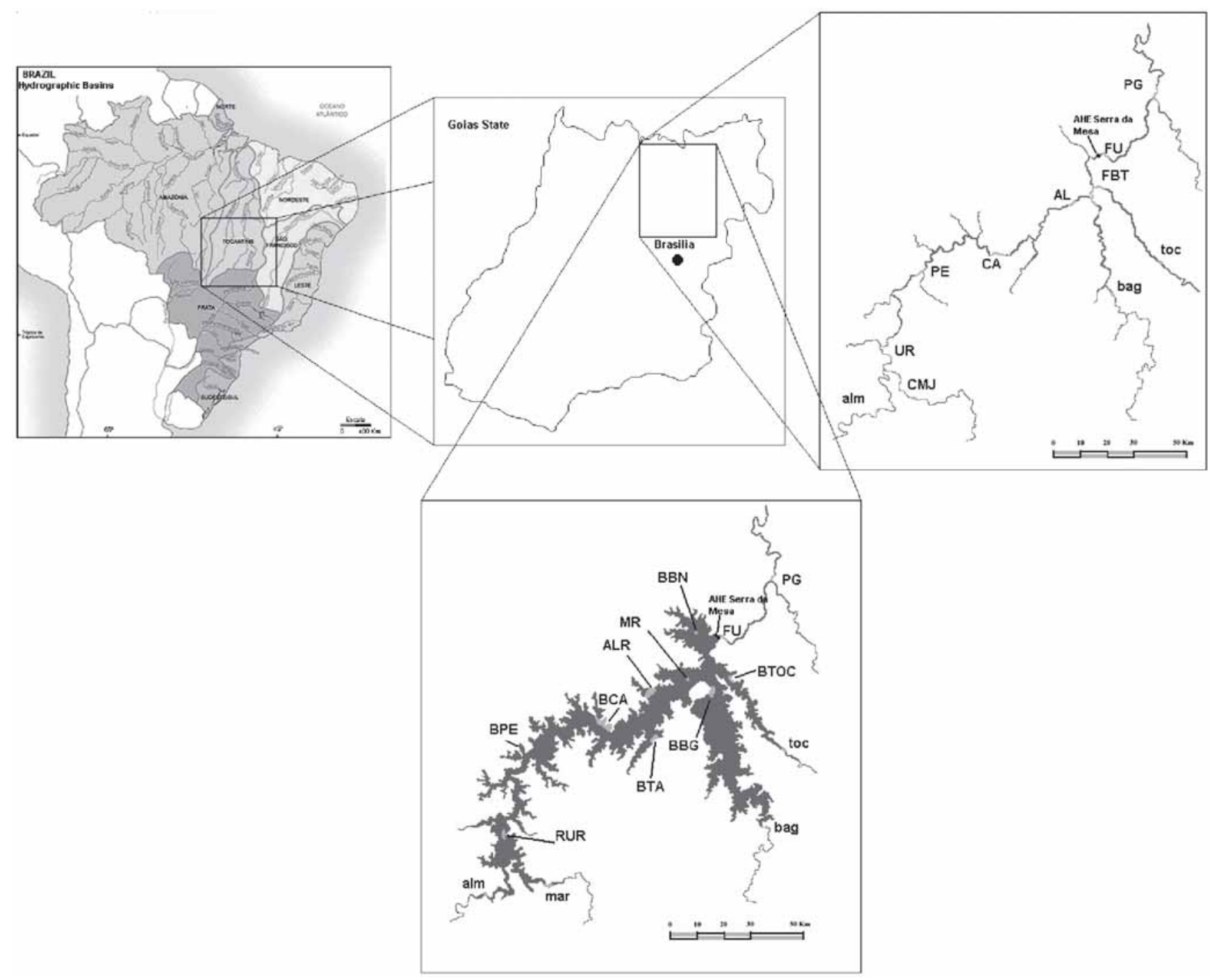

Fig. 1. Location of the upper rio Tocantins, showing the region where the Serra da Mesa hydroelectric plant was installed. Details show sampling sites during the river (top on the right) and reservoir phases.

fruits) was among the main food items in all periods, whereas chironomids were more important during the dry periods, both in the river and reservoir phases. Isoptera was one of the main items during the period of six months after the impoundment (reservoir/ flood), when a substantial increase in consumption of rests of insects was also registered.

When items are assigned as either autochthonous or allochthonous, the former shows a greater importance in the diet of L. taeniofasciatus in all periods analyzed, except during the river/ flood, as shown in Fig. 3. The lowest and highest percentages were found during the high waters and the low waters in the river phase, respectively (Fig. 3). Stomachs with different degrees of fullness had nearly the same percentage of occurrence (Fig. 4), indicating a similar feeding activity both in the river and in the reservoir.

The statistical analysis showed highly significant differences in the diet of $L$. taeniofasciatus between high waters and low waters in the river phase, and between lotic and lentic sites (Table 2). Remaining lotic sites in the reservoir phase were not significantly different from the river phase. The six-month period right after the damming showed a significantly different diet composition for L. taeniofasciatus when compared to all the other periods (Table 2).

\section{Discussion}

The diet of Leporinus taeniofasciatus is comprised of both vegetal and animal resources, characterizing an omnivorous feeding habit. The substantial amounts of sediment and benthic organisms such as insect larvae and filamentous algae in the stomach contents indicate a bottomassociated feeding behavior. This evidence is also supported by its subterminal mouth (Albrecht et al., 2001), although mouth position is not always a strict indication of feeding habit for anostomids (Santos \& Rosa, 1998).

Gerking (1994) utilized the term particulate feeders for 


$$
\text { a. }
$$
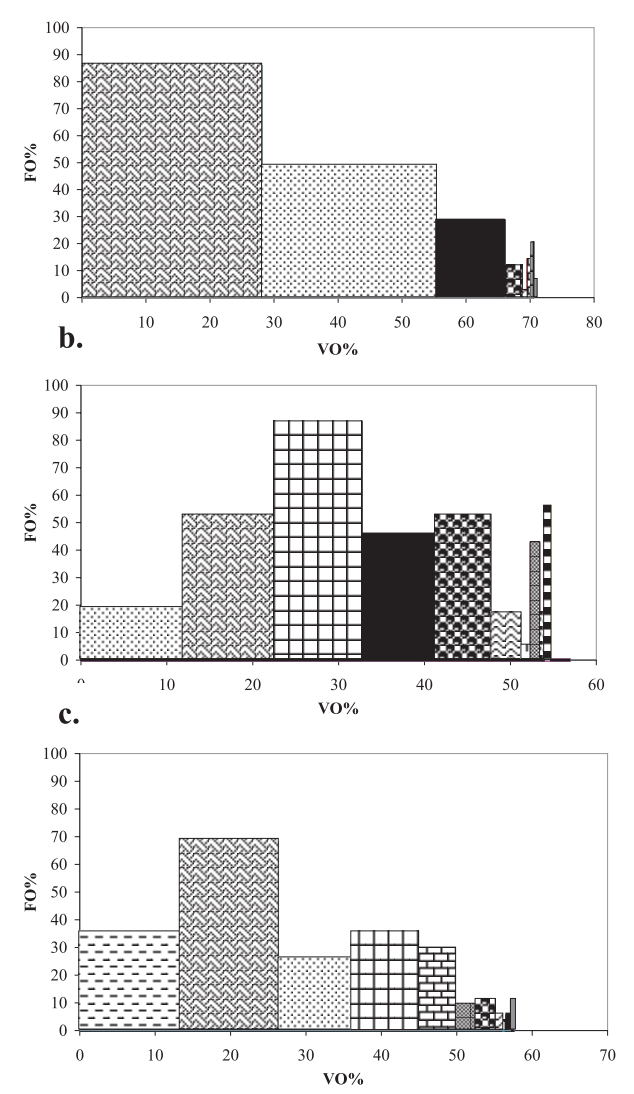

d.

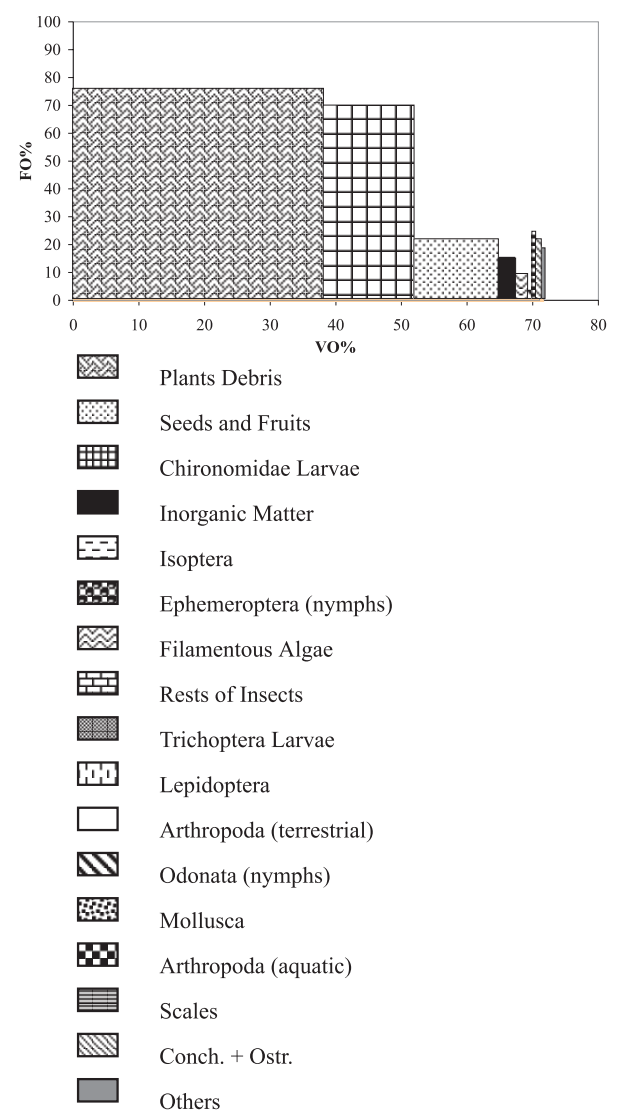

Fig. 2. Representation of the main food items, except organic matter (OM), in the diet of Leporinus taeniofasciatus in the upper rio Tocantins, region of Serra da Mesa. a. River/ flood; b. River/ drought; c. Reservoir/ flood; d. Reservoir/ drought.

species that use visual cues to search and capture small, living food items, which seems to be the case for L. taeniofasciatus. Keenleyside (1979) suggests that cladocerans and cyclopoid copepods, which are relatively weak swimmers, would thus be caught by particulate feeding. These were, in fact, the only zooplanktonic organisms found, albeit never in great amounts, in the stomach contents of L. taeniofasciatus. Their relative scarcity is probably a consequence of not being strained from the water by the gill raker apparatus (Albrecht et al., 2001). Furthermore, the searching behavior of diurnally active fishes, as L. taeniofasciatus is (pers. obs.), shows the importance of vision in this feeding process.

Fishes are highly responsive to seasonal changes in food availability (Hart, 1986; Lowe-McConnel, 1987), a tendency clearly observed in the diet of L. taeniofasciatus. During the flood period, vegetal resources and organic matter, probably of allochthonous origin, were the most abundant items. It seems to be energetically more advantageous to catch drift items that fall into the water than to make the effort to sink and hold position for bottom feeding. Another interpretation is that washing out of invertebrates is one of the immediate effects of floods on stream ecosystems in general, thus affecting short-term feeding opportunities for fish (Matthews,
1998). Increased turbidity can also be regarded as a factor changing foraging regime of fish either directly by interfering with visual references to search for food, or indirectly by reducing primary production (Matthews, 1998). There is a great deal of literature reporting seasonal dietary shifts with a higher consumption of allochthonous items during the high water seasons (e.g. Goulding, 1980; Angermeier, 1982; Braga, 1990; Winemiller \& Jepsen, 1998; Albrecht \& Caramaschi, 2003).

During the low water periods, L. taeniofasciatus seems to have been found closer to the bottom. This increases the likelihood of encounters with epibenthic prey and explains the increased consumption of non-drifting items such as chironomid and trichopteran larvae, and ephemeropteran nymphs. Chironomids are the most abundant and diversified components of benthic macroinvertebrate community (Strixino \& Trivinho-Strixino, 1998), and play an important role in the diet of L. taeniofasciatus, mainly in the dry period. Likewise, benthic microcrustaceans (ostracods and conchostraceans) were more important during the dry season, when cladocerans and copepods were absent. Aquatic arthropods, primarily water mites, were much more frequently preyed upon within the flood period, but presented a low IAi value exactly due to the small 


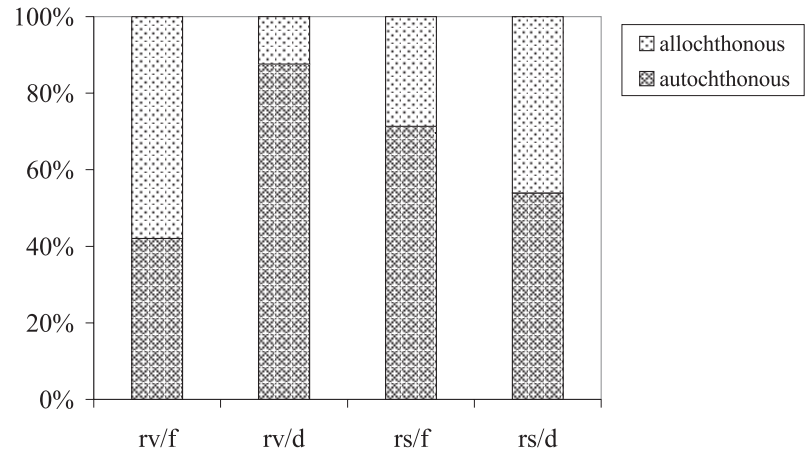

Fig. 3. Proportion of autochthonous and allochthonous items in the stomach contents of L. taeniofasciatus (based on IAi values) in the upper rio Tocantins before and during reservoir formation: River/ flood (rv/f); River/ drought (rv/d); Reservoir/ flood 1 (rs/f1); Reservoir/ drought (rs/d).

size of mites. Other aquatic arthropods like coleopterans or hemipterans were rarer. Although aquatic insects are widely distributed, they are not easily captured due to their fast and irregular swimming behavior (Andrian et al., 1994).

Although IAi, VO\% and $\mathrm{FO} \%$ are average values, which might create biased results that neglect individual variations, their assessment is useful to detect changes at the population level. Indeed, individual variations proved to be very high within the groups, as the percentage explained by the analyzed factors is very low. However, unknown factors other than phase, flow and season could be also contributing to the feeding

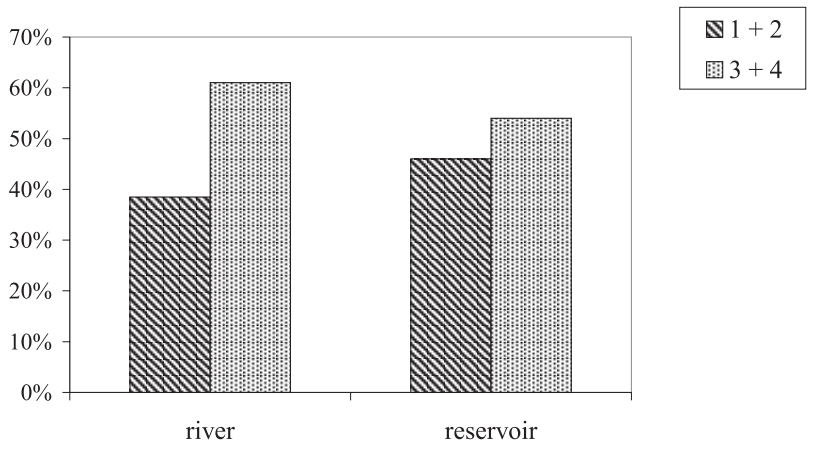

Fig. 4. Percentage of stomachs of L. taeniofasciatus with different degrees of fullness. $1+2=$ half full, and $3+4=$ totally full.

patterns. Fishes are very flexible as can be observed through comparisons between individuals, as well as ontogenetic, seasonal and diel changes in the diet (Gerking, 1994).

During the filling stage several islands were formed, thus providing several shores with abundant food sources. The differentiated seasonal dependence on autochthonous items was not maintained in the reservoir environment. Although the beginning of the filling stage coincides with a flood season, the percentage of allochthonous items was lower than in the river phase. This result, however, can be misleading, as organic matter, considered autochthonous, accounts for

Table 1. Relative volume (VO\%), frequency of occurrence (FO\%) and Alimentary Index (IAi) of food items in the diet of $L$. taeniofasciatus from the upper rio Tocantins before and during the filling stage of the reservoir of the Serra da Mesa Hydroelectric Dam, central Brazil. Reservoir/ lotic comprises both flood and drought seasons during the filling stage, whereas reservoir/ lentic was only sampled during the flood season (up to 6 months after the closure of detour tunnels).

\begin{tabular}{|c|c|c|c|c|c|c|c|c|c|c|c|c|}
\hline \multirow[b]{2}{*}{ food items } & \multicolumn{3}{|c|}{ river/ flood } & \multicolumn{3}{|c|}{ river/ drought } & \multicolumn{3}{|c|}{ reservoir/ lotic } & \multicolumn{3}{|c|}{ reservoir/lentic } \\
\hline & VO (\%) & FO $(\%)$ & IAi*100 & VO (\%) & FO $(\%)$ & $\mathrm{IAi}^{*} \mathbf{1 0 0}$ & VO (\%) & FO $(\%)$ & $\mathrm{IAi}^{*} \mathbf{1 0 0}$ & VO $(\%)$ & FO $(\%)$ & IAi*100 \\
\hline Arthropoda (aquatic) & 0.047 & 5.71 & 0.00422 & 0.575 & 55.93 & 0.50578 & 0.013 & 5.66 & 0.00116 & 0.006 & 2.94 & 0.00031 \\
\hline Chironomidae (pupae and larvae) & 0.112 & 20.00 & 0.03497 & 9.939 & 86.44 & 13.51367 & 6.591 & 47.17 & 4.92896 & 14.645 & 50.00 & 11.93597 \\
\hline Other Diptera (larvae and pupae) & 0.040 & 5.71 & 0.00352 & 0.256 & 55.93 & 0.22491 & 0.030 & 11.32 & 0.00543 & 0 & 0 & 0 \\
\hline Coleoptera (larvae) & 0.028 & 5.71 & 0.00246 & 0.182 & 22.03 & 0.06301 & 0 & 0 & 0 & 0 & 0 & 0 \\
\hline Lepidoptera (larvae) & 0 & 0 & 0 & 1.171 & 5.08 & 0.09368 & 0 & 0 & 0 & 0 & 0 & 0 \\
\hline Trichoptera (pupae and larvae) & 0.002 & 2.86 & 0.00011 & 0.971 & 42.37 & 0.64746 & 3.453 & 7.55 & 0.41316 & 0.087 & 8.82 & 0.01251 \\
\hline Ephemeroptera (nymphs) & 2.457 & 11.43 & 0.43694 & 6.251 & 52.54 & 5.16618 & 3.157 & 9.43 & 0.47215 & 0.106 & 5.88 & 0.01017 \\
\hline Odonata (nymphs) & 0 & 0 & 0 & 0.490 & 3.39 & 0.02612 & 0 & 0 & 0 & 0.573 & 5.88 & 0.05492 \\
\hline Arthropoda (terrestrial) & 0.002 & 2.86 & 0.00011 & 0.079 & 6.78 & 0.00841 & 0 & 0 & 0 & 1.167 & 5.88 & 0.11187 \\
\hline Isoptera & 0.008 & 2.86 & 0.00035 & 0.018 & 3.39 & 0.00094 & 6.045 & 7.55 & 0.72337 & 16.244 & 44.12 & 11.68201 \\
\hline Rests of Insects & 0.430 & 14.29 & 0.09551 & 0.328 & 15.25 & 0.07861 & 4.312 & 20.75 & 1.4188 & 3.055 & 26.47 & 1.31809 \\
\hline Cladocera + Copepoda & 0.032 & 2.86 & 0.00141 & 0 & 0 & 0 & 0 & 0 & 0 & 0.006 & 2.94 & 0.00031 \\
\hline Conchostraca + Ostracoda & 0.007 & 8.57 & 0.00095 & 0.290 & 15.25 & 0.06961 & 0.001 & 1.89 & 4.3E-05 & 0.212 & 5.88 & 0.02034 \\
\hline Mollusca (Gastropoda + Bivalvia) & 0.316 & 8.57 & 0.04211 & 0.681 & 16.95 & 0.18143 & 0.310 & 9.43 & 0.04634 & 0 & 0 & 0 \\
\hline Invertebrate Eggs & 0.002 & 2.86 & 0.00011 & 0.135 & 15.25 & 0.03233 & 0.130 & 13.21 & 0.02716 & 0.129 & 5.88 & 0.01241 \\
\hline Rests of Fish & 0.047 & 2.86 & 0.00211 & 0.077 & 5.08 & 0.00612 & 0.072 & 1.89 & 0.00216 & 0.366 & 5.88 & 0.03509 \\
\hline Scales & 0.007 & 8.57 & 0.00095 & 0.537 & 23.73 & 0.20043 & 0.180 & 20.75 & 0.05908 & 0.019 & 8.82 & 0.00275 \\
\hline Plant Debris & 28.023 & 85.71 & 37.38185 & 10.640 & 52.54 & 8.79371 & 24.554 & 73.58 & 28.6464 & 10.711 & 67.65 & 11.81132 \\
\hline Seeds and Fruits & 27.071 & 48.57 & 20.46328 & 12.075 & 18.64 & 3.54116 & 11.273 & 33.96 & 6.07033 & 9.758 & 8.82 & 1.40352 \\
\hline Filamentous Algae & 1.029 & 2.86 & 0.04573 & 3.598 & 16.95 & 0.95930 & 1.214 & 7.55 & 0.14528 & 0.942 & 5.88 & 0.09031 \\
\hline Organic Matter & 29.418 & 80.00 & 36.62635 & 43.006 & 88.14 & 59.62169 & 37.217 & 96.23 & 56.7802 & 41.337 & 91.18 & 61.43708 \\
\hline Inorganic Matter & 10.923 & 28.57 & 4.85696 & 8.704 & 45.76 & 6.26543 & 1.448 & 11.32 & 0.25995 & 0.636 & 5.88 & 0.06102 \\
\hline$n$ & & 37 & & & 59 & & & 59 & & & 28 & \\
\hline
\end{tabular}


more than $60 \%$. Isoptera, which was a rather chance item in the diet of $L$. taeniofasciatus in the natural environment, becomes one of the most important items during the filling stage. This importance is detectable mainly in the six first months after the dam closure, which also coincides with the seasonal flood period. As isopterans are also very rare during the natural high waters, and as it is present only in specimens from lentic sites, we can deduce that it became available as a consequence of reservoir formation, being readily incorporated into L. taeniofasciatus diet. Their amount, however, declined rapidly following the initial reservoir filling stage and became absent from stomach contents in the following six months. From this period on, alterations in the diet of $L$. taeniofasciatus in the reservoir were not verifiable, as the species became restricted to lotic sites.

Quirós \& Boveri (1999) state that the change from a high flow to a low flow system tends to select a few riverine species previously adapted to floodplain habitats. Considering the degree of stomach fullness, the feeding activity of L. taeniofasciatus was not highly affected in the new lentic environment. Although the availability of food influences the amount consumed (Lagler et al., 1997), in the case of anostomids, feeding activity is also reported to be related to reproduction periods (Barbieri \& Garavello, 1981; Santos, 1982). Lima (2000) showed that L. taeniofasciatus used the sampled area in the riverine environment as a spawning site and that its reproduction activity in the area was jeopardized by dam construction. Simultaneously, a rise in the condition factor (K) occurred in the reservoir (Lima, 2000). It can thus be interpreted that $L$. taeniofasciatus fed on highly energetic food sources during the filling stage but was not able to convert such gains into reproduction. Fish can change allocations of resources according to environmental conditions and population densities (Lowe-McConnel, 1987). The dam created a new, more homogeneous environment, where this species at first profited from the greater food supply. However, despite this plasticity, other factors may have subsequently affected the permanence of the species in the reservoir. The lack of lotic and heterogeneous microhabitats may have increased its vulnerability to other biotic factors such as predation and competition. Therefore, although indirectly, the diet of L. taeniofasciatus was affected by the reservoir formation.

This shift was accompanied by a sharp decrease in the capture of $L$. taeniofasciatus from the lentic environment, beginning in the ninth month after the start of the filling stage (Mazzoni \& Petito, in press). Consequently, the feeding ecology of this species could no longer provide direct responses to questions about further environmental changes in the reservoir. Most of individuals representing the reservoir/ drought group originated from lotic sites. It could be thus expected that the periodicity was maintained, what was not observed, as the period corresponding to low waters in the reservoir differs from the drought period in the river, but not from the flood. In contrast, the fact that its diet did not vary significantly in lotic sites as a whole between the distinct periods (river and reservoir phases) indicates that the river environment still provides favorable conditions for this species.

Our results reinforce the need to preserve remaining upstream lotic environments, such as the rios Maranhão and Almas. Leporinus taeniofasciatus, which is by now believed to be endemic to the Tocantins basin, may be seriously threatened and such free flow habitats are critical to its survival.

Table 2. Probabilities generated in the randomization test of the independence of diet composition of L. taeniofasciatus from season and reservoir formation $(\alpha \leq 0.05)$. Stomach contents are assigned to groups defined by the combination of (1) phase/ season, and (2) phase/ flow. Contrast coefficients specify which cases are compared, as follows: river/ flood (rv/f), river/ drought (rv/d), reservoir/ flood (rs/ f) and reservoir/ drought (rs/d) for group 1, and river/lotic (rv/lt), reservoir/lotic (rs/lt) and reservoir/ lentic (rs/ln) for group 2.

\begin{tabular}{|c|c|c|c|c|c|}
\hline \multicolumn{4}{|c|}{$\begin{array}{c}\text { Source of variation } \\
\text { phase/season: }\end{array}$} & $\begin{array}{c}\text { sum of squares } \\
5.8848\end{array}$ & $\begin{array}{c}\mathrm{P} \\
0.001\end{array}$ \\
\hline \multicolumn{6}{|c|}{ Between groups } \\
\hline \multicolumn{6}{|c|}{ Contrasts: } \\
\hline $\mathbf{r v} / \mathbf{f}$ & rv/d & $\mathbf{r s} / \mathbf{f}$ & $\mathbf{r s} / \mathbf{d}$ & & \\
\hline 1 & -1 & 0 & 0 & 3.931 & 0.001 \\
\hline 1 & 0 & -1 & 0 & 2.729 & 0.001 \\
\hline 1 & 0 & 0 & -1 & 0.62823 & 0.117 \\
\hline 0 & 1 & -1 & 0 & 1.0152 & 0.016 \\
\hline 0 & 1 & 0 & -1 & 1.9409 & 0.001 \\
\hline 0 & 0 & 1 & -1 & 1.2956 & 0.008 \\
\hline \multicolumn{6}{|c|}{ phase/flow: } \\
\hline Betwe & n grol & & & 1.5899 & 0.023 \\
\hline \multicolumn{6}{|c|}{ Contrasts: } \\
\hline $\mathbf{r v}$ & rs/lt & $\mathrm{rs} / \mathrm{ln}$ & & & \\
\hline 1 & -1 & 0 & & 0.63249 & 0.131 \\
\hline 1 & 0 & -1 & & 0.90213 & 0.033 \\
\hline 0 & 1 & -1 & & 0.93169 & 0.029 \\
\hline \multicolumn{4}{|c|}{ phase/season $x$ phase/flow } & -0.1269 & 0.655 \\
\hline \multicolumn{4}{|c|}{ Between groups } & 7.3478 & 0.001 \\
\hline \multicolumn{4}{|c|}{ Within groups } & 58.951 & \\
\hline \multicolumn{4}{|l|}{ Total } & 66.299 & \\
\hline
\end{tabular}

\section{Acknowledgements}

This work was supported by funds from the UFRJ/ BIORIO/FURNAS-Serra da Mesa Energia S.A. programme. CNPq (Conselho Nacional de Pesquisa e Desenvolvimento) granted the scholarship to the first author. We are also very grateful to Richard Vari for revising the manuscript, to Valério Pillar for conceding the MULTIV program for statistical analyses, and to Mary M. Stalcup for helping with the English version. 


\section{Literature Cited}

Agostinho, A. A., H. F. Júlio Jr. \& J. R. Borghetti. 1992. Considerações sobre os impactos dos represamentos na ictiofauna e medidas para sua atenuação. Um estudo de caso: reservatório de Itaipu. Revista UNIMAR, 14:89107.

Agostinho, A. A., L. E. Miranda, L. M. Bini, L. C. Gomes, S. M. Thomaz \& H. I. Suzuki. 1999. Patterns of Colonization in Neotropical Reservoirs, and Prognoses on Aging, Pp. 227-266. In J. G. Tundisi \& M. Straškraba (Eds). Theoretical Reservoir Ecology and its Applications. São Carlos, International Institute of Ecology, 585p.

Albrecht, M. P., M. F. N. Ferreira \& E. P. Caramaschi. 2001. Anatomical features and histology of the digestive tract of two related neotropical omnivorous fishes (Characiformes; Anostomidae). Journal of Fish Biology, 58:14191430.

Albrecht, M. P. \& E. P. Caramaschi. 2003. Feeding Ecology of Leporinus friderici (Teleostei; Anostomidae) in the upper Tocantins river, central Brazil, before and after installation of a hydroelectric plant. Studies on Neotropical Fauna and Environment, 38:33-40.

Andrian, I. F., F. A. Lansac-Tôha \& L. F. Alves. 1994. Entomofauna disponível para a alimentação de peixes comedores de superfície, em duas lagoas da planície de inundação do alto rio Paraná, Brasil. Revista UNIMAR, 16:117-126.

Angermeier, P. L. 1982. Resource seasonality and fish diets in an Illinois stream. Environmental Biology of Fishes, 7:251264.

Barbieri, G. \& J. C. Garavello. 1981. Sobre a dinâmica da reprodução e da nutrição de Leporinus friderici Bloch, 1794 na Represa do Lobo, Brotas-Itarapina, SP (Pisces, Anostomidae). Pp. 347-387. In Anais do Seminário Regional de Ecologia III, São Carlos, SP.

Braga, F. M. de S. 1990. Aspectos da reprodução e alimentação de peixes comuns a um trecho do rio Tocantins entre Imperatriz e Estreito, Estados do Maranhão e Tocantins, Brasil. Revista Brasileira de Biologia, 50:547-558.

Britski, H. A. 1997. Descrição de duas espécies novas de Leporinus dos rios Araguaia e Tocantins, e comentários sobre as demais espécies do gênero assinaladas na bacia (Ostariophysi, Characiformes, Anostomidae). Comunicações do Museu de Ciência e Tecnologia da PUCRS, 10:2743.

Felfili, J. M. \& M. C. Silva Jr. 1993. A comparative study of cerrado (sensu stricto) vegetation in Central Brazil. Journal of Tropical Ecology, 9:277-289.

Figueiredo, C. A. A., D. F. Moraes Jr., R. Bartolette \& E. Pellegrini-Caramaschi. (in press). Composição taxonômica da ictiofauna da área da UHE Serra da Mesa. Cap. 2 In R. Mazzoni, E. Pellegrini-Caramaschi \& R. Iglesias-Rios (eds.) Ictiofauna do alto rio Tocantins: um estudo de caso e subsídios para o manejo no reservatório de Serra da Mesa. Ciência e Paz, Rio de Janeiro, 2003.
Gerking, S. D. 1994. Feeding Ecology of Fish. Academic Press, San Diego. 416 p.

Géry, J. 1977. Characoids of the world. T.F.H., Neptune City. $672 \mathrm{p}$.

Goulding, M. 1980. The fishes and the forest - Explorations in Amazonian natural history. University of California, Berkeley. 280 p.

Hahn, N. S., R. Fugi, V. L. L. Almeida, M. R. Russo \& V. E. Loureiro. 1997. Dieta e atividade alimentar de peixes do reservatório de Segredo. Pp. 141-162. In A. A Agostinho \& L. C. Gomes (Eds.) Reservatório de Segredo - bases ecológicas para o manejo EDUEM Nupelia, Maringá. 387 p.

Hart, P. J. B. 1986. Foraging in Teleost Fishes. Pp 211-233. In T. Pitcher (Ed.). The Behaviour of Teleost Fishes. Croom Helm, London. 553 p.

Hynes, H. B. N. 1950. The food of freshwater sticklebacks (Gasterosteus aculeatus and Pygosteus pungitius) with a review of methods used in studies of the food of fishes. Journal of Animal Ecology, 19:36-58.

Hyslop, E. J. 1980. Stomach contents analysis - a review of methods and their application. Journal of Fish Biology, 17:411-29.

Kawakami, E. \& G. Vazzoler. 1980. Método gráfico e estimativa de índice alimentar aplicado no estudo de alimentação de peixes. Boletim do Instituto Oceanográfico de São Paulo 29:205-207.

Keenleyside, M. H. A. 1979. Diversity and Adaptation in Fish Behaviour. Springer, New York. 208 p.

Lagler, K. F., J. E. Bardach, R. R. Miller \& D. R. M. Passino. 1997. Ichthyology. Wyles, New York. 545 p.

Lima, D. 2000. Abundância, estrutura da população e aspectos da reprodução de duas espécies de Leporinus (Teleostei, Anostomidae) no alto rio Tocantins antes, durante e após a formação do reservatório da UHE Serra da Mesa. Unpublished M. Sc. thesis, Universidade Federal do Rio de Janeiro, Rio de Janeiro. 144p.

Lowe-McConnel, R. H. 1987. Ecological studies in tropical fish communities. Cambridge University, Cambridge. 382 p.

Matthews, W. J. 1998. Patterns in Freshwater Fish Ecology. Chapman \& Hall, Norwell. $756 \mathrm{p}$.

Mazzoni, R. \& J. T Petito. (in press). Distribuição, abundância e estrutura das populações de peixes antes e depois do represamento. Cap. 4. In R. Mazzoni, E. Pellegrini-Caramaschi \& R. Iglesias-Rios (Eds.) Ictiofauna do alto rio Tocantins: um estudo de caso e subsídios para o manejo no reservatório de Serra da Mesa. Ciência e Paz, Rio de Janeiro, 2003.

Merona, B., J.L. de Carvalho \& M. M. Bittencourt. 1987. Les effects imédiats de la fermature du barrage de Tucuruí sur l'ichtyofaune en aval. Revue Hidrobiologie Tropicale, 20:73-84.

Pellegrini-Caramaschi, E., M. F. Valentim \& D. Lima. (in press). Estrutura reprodutiva das populações de peixes antes e depois do represamento, Cap. 6. In Mazzoni, R., E. Pellegrini-Caramaschi \& R. Iglesias-Rios (Eds.) Ictiofauna do alto rio Tocantins: um estudo de caso e subsídios para o manejo no reservatório de Serra da Mesa. Ciência e Paz, Rio de Janeiro, 2003. 
Pillar, V.P. 1999. MULTIV, software para análise multivariada e testes de aleatorização. Porto Alegre, Departamento de Ecologia, Universidade Federal do Rio Grande do Sul.

Pillar, V. P. \& L. Orlóci. 1996. On randomization testing in vegetation science: multifactor comparisons of relevé groups. Journal of Vegetation Science, 7:585-592.

Quirós, R. \& M. B. Boveri. 1999. Fish Effects on Reservoir Trophic Relationships, Pp. 529-546. In Tundisi, J. G. \& M. Straškraba (Eds.). Theoretical Reservoir Ecology and its Applications. International Institute of Ecology, São Carlos. 585p.

Santos, G. M. 1982. Caracterização, hábitos alimentares e reprodutivos de quatro espécies de "aracus" e considerações ecológicas sobre o grupo no lago Janauacá - AM. (Osteichthyes, Characoidei, Anostomidae). Acta Amazonica, 12:713-39.
Santos, G. M. \& P. S. Rosa. 1998. Alimentação de Anostomus ternetzi e Synaptolaemus cingulatus, duas espécies de peixes amazônicos com boca superior. Revista Brasileira de Biologia, 58:255-262.

Strixino, G. \& S. Trivinho-Strixino. 1998. Povoamentos de Chironomidae em lagos artificiais. Pp. 141-154. In Nessimian, J. L. \& A. L. Carvalho (Eds.). Ecologia de Insetos Aquáticos. Oecologia Brasiliensis V, Universidade Federal do Rio de Janeiro.

Winemiller, K. O. \& D. B. Jepsen. 1998. Effects of seasonality and fish movement on tropical river food webs. Journal of Fish Biology, 53:267-296.

Received June 11, 2003

Accepted August 25, 2003 